\title{
ASPECTS OF THE EUROPEAN NATURAL GAS MARKET IN THE DYNAMIC CONTEXT OF GLOBAL ENERGY RESOURGES
}

\author{
Mihai Ioan ACHIM ${ }^{\text {a* }}$ \\ a) Babeș-Bolyai University, Faculty of Economics and Business Administration, \\ Cluj-Napoca, Romania
}

Please cite this article as:

Article History:

Achim, M.I., 2020. Aspects of the European natural Received: 27 November 2019 gas market in the dynamic context of global energy Accepted: 23 September 2020 resources. Review of Economic Studies and Research

Virgil Madgearu, 13(2), pp.5-26.

doi: 10.24193/RVM.2020.13.57.

Abstract: The purpose of this article is to illustrate the structural changes of the European natural gas market through the lenses of the dynamic economic relations between European Union and its biggest energy supplier, Russia. The economic and political aspects are two essential dimensions to understand the measures taken by the EU in order to assure their security of supplies and at the same time to observe the Russian capacities to maximize their profits driven from its vast energy resources. Otherwise Russia is experiencing some difficulties in increasing its export shares on the European gas market, owing to several geopolitical challenges. Nevertheless, the relation between these two blocks could be defined as one of interdependence and symbiosis due to the evolution of the energy trade agreements. We attempt to identify those different market fundamentals and economic processes that have led to the mismatch between the crescent liberalisation in the EU gas sector and the Russian approach to energy market governance.

Key words: energy resources; gas supply; security of supply; pipeline network JEL Classification: Q4O; Q41; Q43; Q34; Q35; Q37

(C) 2020 Alma Mater Publishing House. All rights reserved.

* Corresponding author. E-mail address: achimm_aut@yahoo.com. 
Review of Economic Studies and Research Virgil Madgearu, 2020, 13(2)

\section{References:}

1. Beckman, K. and van den Beukel, J., 2019. The great Dutch gas transition, [online] The Oxford Institute of Energy Studies. Available at: < https://www.oxfordenergy.org/wpcms/wp-content/ uploads/2019/07/The-great-Dutch-gas-transition-54.pdf > [Accessed 15 Mai 2020].

2. Behn, D. and Pogoretskyy, V., 2012. Tensions between the Liberalist and Statist Approaches to Energy Trade Governance: The case of dual pricing. In C. Kuzemko, A. Belyi, A. Goldthau and M. Keating eds. 2012. Dynamics of Energy Governance in Europe and Russia. London: Palgrave Macmillan. pp.45-65.

3. British Petroleum, 2020. Statistical Review of World Energy [online] Available at: <https://www.bp.com/content/dam/bp/business-sites/ en/global/corporate/pdfs/energy-economics/statistical-review/bpstats-review-2018-full-report.pdf $>$ [Accessed 10 August 2020].

4. Correljé, A. 2016. The European Natural Gas Market. Current Sustainable/Renewable Energy Reports, 3, pp.28-34.

5. Cragg, C., 2013. History of the Gas Industry. In: R. Dannreuther and W. Ostrowski, eds. 2013. Global Resources - Conflict and Cooperation. London: Palgrave Macmillan, pp.59-78.

6. Develi, A., Ay, A. and Karaçor, Z., 2012. Increasing Energy Demand of the EU and Turkey's Role in Supplying Energy to the EU: Analyzing the Mutual Costs and Benefits. In A. Develi and S. Kaynak, eds. 2012. Energy Economics. Frankfurt am Main: Peter Lang, pp.39-50.

7. Dannreuther, R., 2013. The Dynamics of Conflict and Cooperation, In: R. Dannreuther and W. Ostrowski, eds. 2013. Global Resources - Conflict and Cooperation. London: Palgrave Macmillan, pp.79-97.

8. Egging, R.G. and Gabriel, S.A., 2006. Examining market power in the European natural gas market. Energy Policy, 34(17), pp.2762-2778.

9. Eurostat, 2019. EU energy in figures - Statistical pocketbook 2019 [online] Available at: <https://op.europa.eu/en/publicationdetail/-/publication/e0544b72-db53-11e9-9c4e-01aa75ed71a1> [Accessed 10 August 2020].

10. Gilardoni,A., 2008. The WorldMarketfor Natural Gas-Implications for Europe. Berlin: Springer.

11. Harsem, Ø. and Claes, D., 2013. The interdependence of EuropeanRussian energy relations. Energy Policy, 59, pp.784-791. https:// doi.org/10.1016/j.enpol.2013.04.035. 
Achim, Aspects of the European Natural Gas Market...

12. Heinrich, A., 2014. Export Pipelines in Eurasia. In A. Heinrich and H. Pleines, eds. 2014. Export Pipelines form the CIS Region Geopolitics, Securization and Political Decision-making. Stuttgart: ibidem-Verlag.

13. Pirani, S. and Sharples, J. 2020. The Russia-Ukraine gas transit deal: opening a new chapter, [online] The Oxford Institute of Energy Studies. Available at: <https://www.oxfordenergy.org/wpcms/wpcontent/uploads/2020/02/The-Russia-Ukraine-gas-transit-dealInsight-64.pdf $>$ [Accessed 30 July 2020].

14. Proedrou, F., 2018. Russian Energy Policy and Structural Power in Europe. Europe-Asia Studies, 70(1), pp.75-89. https://doi.org/10.1 080/09668136.2017.1419169.

15. Prontera, A., 2020. Italy, Russia and the Great Reconfiguration in East-West Energy Relations. Europe-Asia Studies. https://doi.org/1 0.1080/09668136.2020.1767759.

16. Rakos, I., 2015. New Dimensions of the Extractive Industry in the National and Global Context, no. 3, Romanian Academy Institute for World Economy, Available at: <http://www.nos. iem.ro/bitstream/handle/123456789/110/Rakosi_Drobeta. pdf? sequence $=1 \&$ isAllowed $=\mathrm{y}>$ [Accessed 12 July 2020].

17. Rodríguez, F.L., Carvajal, A. and Gómez, L. 2020. Evolution of European Union's energy security in gas supply during RussiaUkraine gas crises (2006-2009). Energy Strategy Reviews, 30. https://doi.org/10.1016/j.esr.2020.100518.

18. Sziklai, B., Kóczy, L. and Csercsik, D., 2020. The impact of Nord Stream 2 on the European gas market bargaining positions. Energy Policy, 144. https://doi.org/10.1016/j.enpol.2020.111692.

19. Shakhovskaya L., Timonina V., 2020. Medium-Term Prospects for Russian Cooperation with European Countries in the Natural Gas Market. Eurasian Journal of Social Sciences, 8(2), pp.70-74.

20. Yegorov, Y. and Wirl, F., 2012. Future of Russian Gas and it's Energy Relation with the EU between now and 2020. In A. Develi and S. Kaynak, eds. 2012. Energy Economics. Frankfurt am Main: Peter Lang, pp.65-82.

21. Yermakov, V., 2018. Shrinking surplus: the outlook for Russia's spare gas productive capacity, [online] The Oxford Institute of Energy Studies. Available at: <https://www.oxfordenergy.org/wpcms/ wp-content/uploads/2018/12/Shrinking-surplus-the-outlook-forRussias-spare-gas-productive-capacity-Energy-Insight-42.pdf> [Accessed 3 June 2020]. 